Journal of Southeast Asian

\title{
A Qualitative Study of the Long Term Impact of Welfare Reform on Cambodian American Families
}

Karen Quintiliani

California State University, Long Beach, Karen.Quintiliani@csulb.edu

Follow this and additional works at: https://docs.lib.purdue.edu/jsaaea

Part of the Asian American Studies Commons

\section{Recommended Citation}

Quintiliani, Karen (2014) "A Qualitative Study of the Long Term Impact of Welfare Reform on Cambodian American Families," Journal of Southeast Asian American Education and Advancement: Vol. 9 : Iss. 1, Article 1.

DOI: $10.7771 / 2153-8999.1076$

Available at: https://docs.lib.purdue.edu/jsaaea/vol9/iss1/1

This document has been made available through Purdue e-Pubs, a service of the Purdue University Libraries. Please contact epubs@purdue.edu for additional information.

This is an Open Access journal. This means that it uses a funding model that does not charge readers or their institutions for access. Readers may freely read, download, copy, distribute, print, search, or link to the full texts of articles. This journal is covered under the CC BY-NC-ND license. 
WWW.JSAAEA.org

\title{
A Qualitative Study of the Long Term Impact of Welfare Reform on Cambodian American Families
}

\author{
Karen Quintiliani \\ California State University, Long Beach
}

\begin{abstract}
Many Cambodian American families have struggled on the economic margins since their arrival to the U.S. in the 1980s. To raise families in poverty Cambodians created family survival strategies to buffer themselves against economic uncertainty and the vagaries of the social welfare system. They combine public assistance with formal and informal work activities of family members, including teenagers and young adults, to survive. With the passage of the Personal Responsibility and Work Opportunity Act of 1996 or Welfare Reform, Cambodians lost vital economic resources. Based upon a longitudinal qualitative study from 1998-2007, this article looks back on how first generation Cambodians adjusted to changes in welfare policy practices and how the loss of vital resources impacted the youth (15-19 years old) coming of age in these families. The research findings and family case histories presented in this article illustrate the shared struggle of Cambodian family members in poverty. It reveals the significant challenges second generation Cambodian Americans face to achieve higher education goals when welfare policies systematically undercut family survival strategies.
\end{abstract}

KEYWORDS: Cambodian Americans, welfare reform, poverty

\section{Introduction}

Because of the persistence of the model minority stereotype, Asian American poverty and welfare usage has been largely ignored in public policy discussions and research. In the aggregate, Asian Americans have a lower poverty rate, 9.6\%, than the overall U.S. population, $10.6 \%$ (Hoeffel, Rastogi, Kim, \& Shahid, 2012), which contributes to the model minority stereotype of immigrant success (Cheng \& Yang, 1996). Cambodian, Laotian, and Hmong refugees that came to the United States in the 1980s and 1990s have had the highest rates of poverty and welfare usage overtime (Ong \& Blumenberg, 1994; Portes \& Rumbaut, 1996; Rumbaut 2006), which challenges the model minority stereotype of Asian Americans. Receiving welfare is viewed as an indication that a new immigrant population has not adjusted effectively

\footnotetext{
(c)

SOCRERIGHISRESERVED Readers are free to copy, display, and distribute this article, as long as the work is attributed to the author(s) and the Journal of Southeast Asian American Education \& Advancement, it is distributed for non-commercial purposes only, and no alteration or transformation is made in the work. More details of this Creative Commons license are available at http://creativecommons.org/licenses/by-nc-nd/3.0/. All other uses must be approved by the author(s) or JSAAEA.
} 
to the American system and that this will negatively impact their children's futures (Portes \& Borocz, 1989; Zhou, 1999). For these reasons, the refugee resettlement program has been criticized for creating a new "underclass" of welfare dependents unable to enter the labor force (Palumbo-Liu, 1999; Tang, 2000). This assessment, however, lacks an understanding of the personal circumstances and histories, cultural beliefs, and structural conditions that may lead to the continued need for government assistance by refugees.

Nationally, the Cambodian American poverty rate of $21.6 \%$ is among the highest of all Asian groups regardless of nativity and age (SEARAC, 2011; Takei \& Sakamoto, 2011); and it is slightly below the poverty rates of African Americans, 25.8\%, and Hispanics, 23.2\% (Macartney, Bishaw, \& Fontenor, 2013), indicating how disadvantaged Cambodian Americans are relative to other minority groups. However, it is not conclusive whether high poverty rates of the first generation Cambodian refugees carry over to their native born children (Takei \& Sakamoto, 2011). Their children have made strides in terms of attaining higher education (Sakamoto \& Woo, 2007), the traditional pathway to social mobility and out of poverty, but the results have not been as robust as many would like to see for this population (Wright \& Boun, 2011). Cambodian integration difficulties have been attributed to their harrowing experiences prior to coming to the U.S.

The Cambodian refugees that came in the 1980s and 1990s were genocide survivors and suffered because of physical and mental debilities due to their wartime experiences (Blair, 2000; Marshall, Schell, Elliott, Berthold, \& Chun, 2005; Mollica, Wyshak, \& Lavelle, 1990; Kinzie \& Frederickson, 1984). In 1975 the Khmer Rouge, a radical communist group, seized control of Cambodia in an effort to create an agricultural utopia and to cleanse the country of Western influence (Chandler, 1991). To stifle resistance, the Khmer Rouge used torture and murder to control the population and to eliminate enemies of the state. By 1979, when the Vietnamese invaded Cambodia and toppled the Khmer Rouge, over 2 million Cambodians had died from starvation, disease, and murder (Kiernan, 1996). In the wake of a continued civil war, thousands fled to refugee camps along the Cambodia-Thai border, languishing in deprivation until being selected for resettlement in a Western country (Becker, 1998).

Compared to other Asian immigrants, Cambodian refugees came to the United States under horrific circumstances and did not have the educational, linguistic, or work backgrounds to immediately enter the labor force (Hein, 2006). Their lack of skills combined with the impact of the restructured U.S. economy creates a different and more difficult set of structural conditions for them and their second generation children to navigate than immigrants at the turn of the twentieth century (Gans, 1992; Zhou, 1997). What is less recognized about Cambodians and other Southeast Asian refugees is how they used the social welfare system with formal and informal labor practices to survive in an economic system with few opportunities (Kibria, 1993; Quintiliani, 2009). With the passage of the Personal Responsibility and Work Opportunity Act of 1996, more commonly known as Welfare Reform or the Welfare Act, this survival strategy was undermined at a time when their second generation children were coming of age. In this article, I look back on how first generation Cambodian families adjusted to changes in welfare policy practices and how the loss of vital resources impacted the youth (15-19 years old) in these families. Then, I look forward to how these research findings can inform research on Cambodian American families, issues of poverty, and the possible futures of their children in the postwelfare era. The central research questions addressed in this article are: a) how did Welfare Reform disrupt Cambodian family survival strategies?; and b) how did changes in the economic 
lives of first generation Cambodian families impact the educational and work opportunities of youth coming of age during the implementation of Welfare Reform?

With respect to refugees and Welfare Reform, Cambodians are an important population to understand. Cambodians are one of the largest refugee groups in the United States with over 150,000 admitted since 1975 (Niedzwiecki \& Duong, 2004). There are approximately 307,000 living in the United States today (SEARAC, 2011), illustrating the growing number of people of Cambodian heritage born in the U.S. Over 95,000 Cambodians reside in California, with approximately one-third of the population residing in Los Angeles County (U.S. Census Bureau, 2011). During the 1980s when the largest influx of Cambodian refugees entered the U.S., one city, Long Beach, California, at the southernmost border of Los Angeles County, became the center of the Cambodian diaspora and home to the largest Cambodian community in the U.S. (Chan, 2004; Needham \& Quintiliani, 2007). The poverty rate of Cambodians residing in Long Beach hovers over $30 \%$, which is significantly above the national trend for this population (U.S. Census Bureau, 2010). The research findings discussed in this article are based upon a longitudinal qualitative study of eleven Cambodian American families from 1998 to 2007 in Long Beach, California. This article specifically focuses on first generation families and their second generation children coming of age during Welfare Reform.

\section{Significance of the Study}

Most studies since the implementation of Welfare Reform have focused on the individual workrelated activities of welfare recipients instead of on the way family survival strategies are disrupted by the changes in welfare program practices (Newman, 2001; O'Connor, 2001). Yet, even before Welfare Reform was enacted, working and poor families (immigrant and nonimmigrant) had to develop complex family survival strategies to safeguard themselves against the instability of the low-wage job market and the uncertainty of the welfare system rules regarding eligibility (Edin \& Lein, 1997; Schneider, 2000; Sharff, 1998). It is for these reasons that families on welfare rely on multiple wage earners - including teenagers and young adultsin the family to help make ends meet (Newman 2001, 1999). Even many "successful" Asian immigrant populations historically relied on multiple wage earners in extended family households to lift themselves out of poverty (Toji \& Johnson, 1992), but this reality has been largely ignored since it does not fit with the myth of the model minority stereotype. In the restructured U.S. economy with fewer jobs that pay less, immigrant families turn to the social welfare system when they cannot find work. Immigrant families will also utilize public assistance as a financial strategy for fulfilling family obligations (i.e., child and elder care) and helping their children achieve higher education (Fix \& Zimmermann, 1997; Fuligni \& Yoshikawa, 2004). As a result, the new second generation of children of immigrants and refugees have limited or varied pathways to social mobility (Zhou, Lee, Vallejo, Tafoya-Estrada, \& Xiong, 2008), which contrast with the story of immigrants and their children a century ago (Alba \& Nee, 2003). This article brings into focus the need for research that considers family survival strategies in the wake of the dramatic shifting of public assistance for refugee populations and their children.

Welfare reform has altered immigrant access to vital economic resources during times of job loss and need (Shields, 2004; Singer, 2004). Immigrant populations are more likely to experience greater poverty and deprivation than native-born populations since the advent of Welfare Reform (Fix, Capps, \& Kaushal, 2009; Ng, 2004, 2002). However, little is known about 
the long-term implications of Welfare Reform on different family members especially those coming of age without an economic safety net. Even less is known about refugee families, a group specifically targeted by the Welfare Act for reductions in public assistance (Fujiwara, 2005, 1999).

This article addresses how disruptions in family survival strategies alter the educational opportunities and work aspirations of second generation Cambodian youth growing up with refugee parents on welfare. No other studies documenting the Cambodian experience on welfare and its reform examined the lives of youth growing up during Welfare Reform implementation (Ong, 2003; Truong, 2007; Tang, 2000). The Cambodian families in this study are the only Asian American group to be included in a large-scale national study investigating the impact of welfare reform on families and communities. Although the research findings discussed in this article include a small number of families, and therefore cannot be generalized, it provides a window into the everyday lives and challenges of Cambodian Americans across the generations. This type of in-depth, qualitative research can inform future research and advocacy strategies aimed at advancing the educational attainment of Cambodian Americans and promoting community program development to ameliorate poverty.

\section{Brief Overview of Welfare Reform}

The Welfare Act eliminated welfare as a life-time entitlement and created a time-limited cash assistance program called Temporary Assistance for Needy Families (TANF). The legislation also established strict work requirements for TANF recipients, eliminated federal funding for certain groups of legal immigrants, and transferred the administrative authority for welfare programs from the federal government to the states (Greenberg, 2001). It required recipients to work within two years of receiving benefits, and to meet work participation requirements of at least 20 hours per week. Welfare Reform also limited most adults to five years of aid as a lifetime total, including those months in which the recipient complies with work requirements. The crafting of the Welfare Act also sought to limit or eliminate immigrants' access to government services and assistance. As a result, over half the savings accrued the first year of Welfare Reform was due to reductions in immigrant recipients (Greenberg et al., 2000).

Under the new provisions, noncitizen immigrants were no longer eligible for Supplemental Security Income (SSI) and the Food Stamp program. Legal immigrants, including refugees, were barred from receiving TANF for five years. Elderly and disabled Asian immigrants were specifically casts as a drain on the welfare system. For many older Southeast Asian refugees disabled by their war experiences and limited English capability, this loss of public assistances was devastating (Becker, Beyene \& Ken, 2000; Ong, 2003). The 1997 Balanced Budget Act aimed to restore eligibility for refugees arriving before 1996, but this was not what happened. Instead, many Cambodians and other Southeast Asian refugees who arrived in the 1980s were treated harshly within the system and did not have their benefits restored or it took several years to re-qualify despite high rates of illness, disability, and poverty in this population (Hein, 2006). This study reveals the long-term impact of Welfare Reform and the punitive aspects of the policy on Cambodian American refugee families.

California has the distinction of being the largest immigrant-serving welfare system in the country $(\mathrm{Ng}, 2004)$. The sheer size and diversity of the welfare recipients in California made meeting the federal welfare reform mandates a monumental task. As a result, California was one of the last states to pass welfare reform legislation in response to the federal law. California 
developed CalWORKS (California Work Opportunity and Responsibility to Kids) and the fiveyear clock to obtain a job began ticking on January 1, 1998. Under the new system, welfare recipients attend GAIN (Greater Avenues for Independence) programs in their local communities and must find a job - any job - as quickly as possible to continue to received assistance (Marchevsky \& Theoharis, 2006). Although welfare recipients attend GAIN in their first language, the job program offers little more than motivational messages and sanctions for not finding a job (Horton \& Shaw, 2002; Marchevsky \& Theoharis, 2006).

Under the Welfare Act, states have the authority to create their own Food Stamp and SSI programs to meet the needs of their varied populations, but these programs were funded with state monies and not reimbursed by the federal government. The California legislature in response to political pressure from immigrant rights and advocacy groups crafted their own replacement programs to mitigate the possible impact of child poverty and public health risks (Mautino, 2000). The Cash Assistance Program for Immigrants (CAPI) is a California program aimed at preventing destitution among the aged, blind, disabled and noncitizen ineligible for SSI under the Welfare Act or had been denied services. California went further to prevent child poverty in response to public outcry for a more humane approach to administering public welfare. When parents are unable to find a job within five years or do not meet the GAIN requirements their portion of the federal welfare grant is reduced. However, the family can still receive rent assistance, known as Section 8 Housing, or utility assistance and under age children can continue to receive cash and medical assistance. These state-funded stopgap welfare provisions in California veil the full cost and impact of the Welfare Act on immigrant families as the experiences of Cambodian refugees in this study reveal.

California did not pass Welfare Reform legislation until August 1997. Because of the complexity of the welfare populations in Los Angeles County, the initiation of time limits did not begin until January 1998 with the first time limits occurring in late 1999. Therefore, this study coincided with the implementation and aftermath of the Welfare Act on Cambodian American families.

\section{Description of the Study: $1998-2007$}

The research findings reported in this article are based upon a qualitative study initially funded by the Manpower Demonstration Research Corporation's (MDRC) project called Project on Devolution and Urban Change (herein referred to as the Urban Change Project), a national study in four U.S. cities: Cuyahoga, Ohio; Los Angeles, California; Miami-Dade, Florida; and Philadelphia, Pennsylvania. The Urban Change Project was designed to understand how cities, poor neighborhoods, and low-income families are affected by the fundamental changes to the structure of the social safety net put in motion by the 1996 Welfare Act (Quint et al., 1999).

The Cambodian population was selected for the Urban Change Project because of the large concentration of Cambodians living in contiguous census tracts with poverty rates between 30 and 40 percent in Long Beach, California. In these same census tracts, 20 percent or more of Cambodian families were welfare recipients. The Urban Change Project had established sampling criterion for the qualitative study. The Cambodian women chosen to participate in the study included those recruited from social service agencies and those not associated with an institution. Moreover, once a participant was identified, only one referral from them was allowed to ensure that women in the study were from different social and kin networks. Finally, the Cambodian women recruited into the study were indicative of both short-term welfare recipients 
(e.g., more work experience, better educational credentials, and fewer children) and long-term welfare recipients (e.g., little or no work experience, low levels of education, and more children) (Quint et al., 1999). Based upon this sampling criterion and my research experience in the Cambodian community in Long Beach since 1988, both first generation women $(n=7)$, who came to the United States as adults, and 1.5 generation women $(n=4)$, who arrived as children, were recruited into the study. The recruitment strategy employed resulted in a purposive sampling of Cambodian women in Long Beach. Purposive samples are often used for exploratory research and to select a small number of cases for intensive study (Bernard, 2000). This sampling strategy is also appropriate when studying populations that are hard to reach and thus understudied.

Table 1

Timeline of research methods employed and number research participants in each family (1998-2007)

Dates Research Methods No. of participants

1998- In-depth interviews with Cambodian mothers as

2002 primary recipients of welfare four times per year. This

11 women and their part of the research funded by MDRC as part of the national study. Also, included preliminary observations of family routines.

families until 2002

* One first generation woman and her family moved to Fresno, California with her family.

* One 1.5 generation woman and her family moved out-of-state and could not be located.

1999- Informal interviews and observations of family 2002 routines four times per year. Designed and conducted 10 women and their research independently as an outgrowth of the national study.

families until 2002 *I went to visit the family that moved to Fresno, CA. one time during this research period.

2000- In-depth interviews with youth and young adults living

2002 in the first generation families. Received additional 19 youth/young adults in the 10 families were funding to conduct these interviews independent of the national study.

2003-

2007 Follow-up interviews with mothers and youth/young adults in the families two times per year. Designed and conducted this research as part of an independent interviewed at least one time. project.

9 families, 10

youth/young adults in these families

Table 1 describes the sequence of research methods used during the study period and how I expanded the initial Urban Change Project to include family observations and interviews with youth (15-19 years old). The table also illustrates the number of families and youth involved in the study ${ }^{1}$. For a majority of the study, I was able to maintain regular contact with nine of the families. After 2007, when the study formally ended, I could only contact three of these nine 
families. As jobs became scarcer and their children "aged out" of the system, they had to find opportunities elsewhere, usually out of state, to survive. In one first generation family, the loss of SSI and medical insurance led to a rapid decline in health, and by 2004 both parents had died and their children were scattered among family members or moved out on their own.

As described in Table 1, several different qualitative methods were employed overtime to understand how different family members were impacted by changes in the economic well-being of the family.

\section{Interviews}

The in-depth, open-ended interviews aimed to explore how Cambodian women, as the primary recipients of public assistance, understand and deal with changes to welfare programs and to identify how these changes impact family social, psychological, and economic well-being. The eleven Cambodian women were interviewed at least every 3 months between 1998 and 2002. Each interview covered several topics each year and during follow-up visits. The open-ended interview guide covered the following topics: family background; changes in family composition and marital relations; life on welfare; work incentives and disincentive; budget information; alternatives to welfare-to-work; time limits; neighborhood and community conditions; institutional resources; health and well-being; social network support; and children's health and educational needs. To ensure comprehension of in-depth topics, a native Khmer speaker assisted with these interviews and transcription of the interviews.

After two years of interviews with the Cambodian women and observing family routines, it became apparent the limits of a welfare reform study that did not include youth coming of age during this critical period of economic and social change in their families. In 2001, I initiated a study of the youth ages 15 to 19 in the first generation families. These second generation Cambodian youth were born either in a refugee camp or in the U.S. I conducted open-ended interview with the second generation Cambodian youth in these families. The open-ended interviews covered topics on their perceptions of welfare; work and school histories; aspirations for the future; and family responsibilities. Each youth $(n=19)$ were interviewed at least once.

Between 2003 and 2007, I conducted follow-up interviews with nine out of the eleven women two times per year. The follow-up interviews asked open-ended questions about the current status of the family's welfare benefits and what changes in the family had occurred since the last visits. Ten of the youth participated in these extended interviews and follow-up visits.

\section{Participant Observation}

To understand how first generation Cambodian families made daily adjustments to social welfare policy shifts, I became a participant observer in the daily routines and interactions in each of the eleven families. Systematic observations were conducted to capture key cultural domains relevant to understanding how generational roles and relationships occur in the flow of activity (Lofland \& Lofland, 1984; Spradley, 1980). Observations occurred during family transitions in the morning, afternoon and evenings, taking note of how roles and responsibilities break down by gender and age of all family members and friends. These data also provided an understanding of how families negotiate their economic and social relationships on a day-to-day basis, which would not otherwise be captured through survey and census data. 


\section{Case Study Analysis}

The tape-recorded interviews with the women and youth were transcribed immediately and used to document specific ways family members were affected by welfare changes during and after the implementation of welfare program changes in Los Angeles County. The observational data, which included informal interactions with other family members and friends, were used to triangulate the information gathered from interviews with Cambodian women and youth to confirm their experiences in the context of family life (Fetterman, 1998). Family case histories were constructed from these different data points and sources and analyzed to identify broader themes and patterns regarding family survival strategies (Stake, 2003).

The findings discussed in this article only include the first generation families (and not the 1.5 generation families) and their second generation children.

\section{First Generation Families}

Table 2 illustrates the size and composition of the first generation families and the number of children and youth impacted by changes in the economic lives of their families. The Meng, Uy and Meas families lived in an extended family household that included at least one elderly parent that required caretaking. All the women had husbands that lived in the household except for the Sok and Heang families. Khun Sok's husband died tragically in 1990 and Thida Heang's husband left her.

Table 2

Composition and size of first generation families

\begin{tabular}{|c|c|c|c|c|c|c|}
\hline $\begin{array}{l}\text { Pseudonym } \\
\text { First Name } \\
\text { (Surname) }\end{array}$ & $\begin{array}{l}\text { Age at } \\
\text { Baseline }\end{array}$ & $\begin{array}{l}\text { Arrival } \\
\text { Year }\end{array}$ & $\begin{array}{l}\text { No. } \\
\text { adults }\end{array}$ & $\begin{array}{c}\text { No. } \\
\text { Children } \\
>14\end{array}$ & $\begin{array}{l}\text { No. } \\
\text { Youth } \\
<15\end{array}$ & $\begin{array}{l}\text { Total no. family } \\
\text { members in household }\end{array}$ \\
\hline $\begin{array}{l}\text { Bopha } \\
\text { (Oung) }\end{array}$ & 45 & 1985 & 2 & 4 & 2 & $\mathrm{n}=8$ \\
\hline $\begin{array}{l}\text { Khun } \\
\text { (Sok) }\end{array}$ & 46 & 1981 & 1 & 2 & 3 & $\mathrm{n}=6$ \\
\hline $\begin{array}{l}\text { Phoeun } \\
\text { (Uv) }\end{array}$ & 35 & 1985 & 4 & 4 & 2 & $\mathrm{n}=10$ \\
\hline $\begin{array}{c}\mathrm{Ra} \\
\text { (Prum) }\end{array}$ & 44 & 1985 & 2 & 3 & 3 & $n=8$ \\
\hline $\begin{array}{l}\text { Sitha } \\
\text { (Meas) }\end{array}$ & 35 & 1988 & 3 & 5 & 3 & $\mathrm{n}=11$ \\
\hline $\begin{array}{l}\text { Thida } \\
\text { (Heang) }\end{array}$ & 34 & 1988 & 1 & 3 & 2 & $n=6$ \\
\hline $\begin{array}{c}\text { Yee } \\
\text { (Meng) }\end{array}$ & 48 & 1985 & 4 & 5 & 4 & $\mathrm{n}=13$ \\
\hline
\end{tabular}

These first generation women came to the U.S. in the 1980s during the largest wave of Cambodian migration with their spouses and surviving children. Once in the U.S., they had additional children. All of them came from modest farming backgrounds and lived in rural areas

of Cambodia where educational opportunities were limited or nonexistent. Most of the women 
deferred taking English class or other educational opportunities in order to fulfill their roles as mothers and wives.

They shared horrific stories of being beaten and witnessing the death of loved ones, sometimes their own children, during the Khmer Rouge period. All of the women lost one or more family members or nearly died themselves after being beaten. The consequence of these experiences has been a constant struggle to cope with physical and emotional ailments that intrude on daily functioning.

Table 3

Summary of types of public assistance received and jobs held during study period

\begin{tabular}{|c|c|c|c|}
\hline $\begin{array}{l}\text { Family } \\
\text { Surname* }\end{array}$ & $\begin{array}{l}\text { Public assistance } \\
\text { received overtime }\end{array}$ & $\begin{array}{l}\text { Jobs held by } \\
\text { adults in the families }\end{array}$ & $\begin{array}{l}\text { Jobs held by } \\
\text { youth in the families* }\end{array}$ \\
\hline Heang & $\begin{array}{l}\text { TANF } \\
\text { CAPI }\end{array}$ & Cash jobs & Fast food restaurant \\
\hline Meas & $\begin{array}{l}\text { TANF } \\
\text { CAPI } \\
\text { SSI }\end{array}$ & $\begin{array}{l}\text { Sews in home } \\
\text { IHSS worker }\end{array}$ & Fast food restaurant \\
\hline Meng & $\begin{array}{c}\text { TANF } \\
\text { Section } 8 \text { housing } \\
\text { SSI } \\
\text { CAPI }\end{array}$ & $\begin{array}{l}\text { Sews in home } \\
\text { IHSS worker } \\
\text { Cash jobs }\end{array}$ & $\begin{array}{l}\text { Fast food restaurant } \\
\text { High school tutor and } \\
\text { teacher's aid }\end{array}$ \\
\hline Oung & $\begin{array}{l}\text { TANF } \\
\text { CAPI }\end{array}$ & Sews in home & $\begin{array}{l}\text { Childcare aid } \\
\text { Fast food restaurant }\end{array}$ \\
\hline Prum & $\begin{array}{l}\text { TANF } \\
\text { CAPI }\end{array}$ & Sews in home & Waitress \\
\hline Sok & $\begin{array}{c}\text { TANF } \\
\text { SSI } \\
\text { CAPI } \\
\text { Section } 8 \text { housing }\end{array}$ & $\begin{array}{c}\text { Cash jobs } \\
\text { Factory worker in a } \\
\text { Welfare- to-Work Program }\end{array}$ & $\begin{array}{l}\text { Fast food restaurant } \\
\text { Teacher's aid at } \\
\text { elementary school }\end{array}$ \\
\hline Uy & $\begin{array}{l}\text { TANF } \\
\text { CAPI }\end{array}$ & $\begin{array}{l}\text { Sews in home } \\
\text { IHSS worker } \\
\text { Cash jobs }\end{array}$ & Fast food restaurant \\
\hline
\end{tabular}

Note: Youth worked part-time, usually 20 hours per week. After high school graduation, it was possible to work more hours, but their employers rarely increased their hours above 30 hours per week to avoid them being considered full-time employees. 
All the women said they received Refugee Cash and Medical Assistance for the maximum time allowed from 9 to 18 months depending on the resettlement policy in effect at the time of their arrival. They then applied for and received public assistance because they could not work in formal jobs due to family obligations and their lack of English language ability. Four of the women, Yee, Khun, Ra, and Phouen, received SSI as did the elderly parents living in the extended family. Once Welfare Reform was enacted, SSI was rescinded for all non-citizens, including refugees, until the 1997 Balanced Budget Act restored benefits to refugees who arrived before 1996. However, for the family members under 65 years old, they had to re-qualify for SSI through a physician that verified their inability to work. After an arduous process to re-qualify for SSI, Ming and Khun had their benefits restored.

Their husbands worked in Cambodian owned businesses usually for cash or cycled in and out of factory jobs sometimes even traveling out of state for opportunities. Also, the men living in the extended family households (i.e., Meng, Uy and Meas families) worked as In-Home Supportive Services (IHSS) workers providing care for elderly parents that would otherwise need to in a facility. The program is administered through the Los Angeles County Department of Public Services and "counts" toward fulfilling work requirements under the TANF system. However, none of these jobs provided the family with enough income to survive or with health insurance. To supplement their welfare benefits, all the women at one time or another did sewing jobs or piecework for cash. Sometimes their husbands and children worked with them. The families purchased or borrowed an industrial sewing machine so they could work out of their homes or in the homes of relatives or friends to complete jobs. These informal jobs were difficult and time sensitive, but it allowed them to earn money and fulfill child caretaking responsibilities at the same time. Another source of income came from some of their working age children. These jobs were usually minimum wage and did not offer a career opportunity. As the family case histories discussed in the next section reveal, these jobs helped support their parents and siblings as welfare benefits were cut. Table 3 illustrates the different types of public assistance and jobs used in combination to support each family in the study.

The constant concern of the Cambodian parents in this study was their children's future, particularly their education. Being poor and on welfare makes it difficult to fulfill the parental role for providing children with the material, emotional, and social means to become educated. Phoeun expresses a common feeling:

It's difficult to be on welfare because I don't have any money to spare for my children when they need things. Once my children graduate from high school, they will not be eligible for welfare. I will need money to help them get a car for work and school until they can stand on their own. But I can never save any money on welfare.

All the parents are aware that they need to support their children well into adulthood if they are going to be able to attend college. They are also afraid that their past experiences may influence their children's future. Thida expresses her desire for her children to do well despite the tragedy of Cambodian history:

I don't want my children to suffer and not have formal education like me when I lived under Pol Pot. It's hard to see what their futures will be. I give them advice to study hard and stay away from the wrong crowd and bad deeds. 
Like Thida, many parents know that raising children in the U.S. in a poor neighborhood with few resources makes it even more difficult to guide them, but these parents recognize that education is the pathway to a better life for their children.

\section{Welfare Reform and Living in Poverty}

Even before Welfare Reform, Cambodian families struggled and had to rely upon public assistance in combination with formal and informal work to survive. After Welfare Reform, the struggle intensified for two main reasons. First, the first generation Cambodians in the study were disqualified from receiving Supplement Security Income (SSI) because the new law made US citizenship a requirement to receive federal resources. All the families in this study had at least one adult recipient have their SSI discontinued. This pushed women and men with young children into the CalWORKS system and they received TANF, Temporary Aid for Needy Families, even though they were not physically or mentally equipped to work. Second, the stringent work requirements required by the Welfare Act unduly disadvantaged limited English speakers with few skills to enter the workforce. The implementation of Welfare Reform thus exacerbated the difficulties of Cambodian families relying on public assistance to support their children and disrupted the tenuous family survival strategies employed since their arrival to the U.S. as refugees. The following family case studies illustrate how the passage of the Welfare Act created more suffering in families and limited the educational and work choices of youth in these families. These case studies provide a snapshot of family life based upon an analysis of the multiple data points and sources (e.g., interviews and family observations) collected in each family over a nine-year period.

\section{The Meng Family}

The Meng family is a large extended household comprised of two-parents, Yee (mother) and Virath (father), two elderly grandparents, and seven children ranging in age from 4 to 19 years old. Ming and Virath are in their late forties and have been married for almost thirty years. Their marriage was arranged by their parents when they were teenagers in Cambodia. Together they barely survived the Khmer Rouge's forced labor camps, but lost four of their six children to disease and starvation. Once in a refugee camp, they reunited with Virath's parents and the extended family, including their two surviving children. They were sponsored by a church group and resettled in Long Beach in 1982. Their only other surviving family members were Yee's younger sister and her family who also resettled in Long Beach. The families have lived within a few blocks of each other since their arrival in Long Beach. Yee and Virath began rebuilding their family after the war and had seven more children most of whom were born once they resettled in the Long Beach.

Yee and Virath suffer from severe physical and mental health problems including depression, high blood pressure, and in Virath's case, liver disease. Before the passage of the Welfare Act, Yee received Supplemental Security Income (SSI) due to the severity of her medical conditions. Virath got paid by the State of California as an In-Home Support Service (IHSS) taking care of his two elderly parents, who received SSI for the aged. Their children received AFDC and Medi-Cal (California's version of Medicaid). Even with these sources of public assistance, the family needed to work in the informal work sector to provide for their children's needs. Yee learned basic sewing skills as a child in Cambodia and she used her 
knowledge once in the U.S. doing piecework in the home on an industrial machine the family purchased. Virath, when he felt well enough, worked as a donut baker in a Cambodian friend's shop making \$50 per night. Before the passage of the Welfare Act, Yee and Virath took on these cash jobs when their health permitted.

The Meng family's financial situation immediately changed with the passage of the Welfare Act. In 1997, Yee was disqualified from SSI since she was not a citizen. Subsequently, she was shifted into the CalWORKS program and thus subject to time limits and work requirements to continue to receive benefits. Virath's elderly parents moved to Cambodia the following year out of fear they would also lose their SSI. Although they were mistaken about their eligibility, their reaction mirrored the fear and confusion rippling through the Cambodian community in the wake of welfare reform. Since his parents no longer lived with the family, Virath did not get paid as an IHSS worker and he lost his Medi-Cal benefits as a result, which he desperately needed for the health problems he managed with medication and regular doctor visits.

Once in the CalWORKS program, Yee was required to attend the GAIN program for job training and preparation or be subject to losing her portion of the welfare grant. For Yee, participating in GAIN program seemed like a futile exercise given her family responsibilities and her level of preparedness for the labor market: "I really want to get a job. But how can I if my children need me at home? They are too young and besides nobody hires people who don't speak English and don't have any skills like me." Several times a week the GAIN service worker called Yee prodding her to come to the job training program:

Someone called me from the GAIN program asking why I didn't go to meet them. I told the worker that I was sick. She told me that I would get my Medi-Cal cut since I didn't attend the GAIN appointment. I told her that it's very hard for me to get there because of my health problems. I told her that I would understand if she cut me off. And I told her that I don't want to live anymore; too much pressure.

The GAIN service worker uses the false threat of Yee losing her Medi-Cal benefits, the California medical insurance for the poor, disabled, and elderly, as a ploy to get her to attend the job training program. Yee does end up losing $\$ 150$ per month for not attending GAIN, but not her Medi-Cal. Even this amount causes the family greater personal and financial hardship.

Exacerbating the situation even more was Virath's continued failing health, which prevented him from working even the cash jobs in Cambodian businesses. Moreover, he starts going to a traditional healer and an herbalist to control his high blood pressure, which cost the family money they do not have. The family's financial situation is further complicated by Suny, the oldest son, who started ditching high school and hanging out with the wrong crowd. Because he is not attending school and ends up in a juvenile detention center for truancy, his portion of the welfare grant is discontinued. In desperation, Yee contracts more sewing jobs, which worsens her health problems:

I do everything at the same time. When my kids are home, I stop and start cooking for them. When I sew I still try to watch them and tell them what to do. Sometimes when they are asleep, I sew till midnight. When I lack sleep and sit too long at the sewing machine, my blood pressure goes up and I have dizzy spells. I don't think I will live a longer life. 
The financial and health difficulties in the family particularly affected Kolab, the oldest daughter.

Kolab was a junior in high school with a 3.5 grade point average when the family's financial situation started to worsen. However, Yee and Virath, as did Kolab, believed she would be able to attend a four-year university despite the financial instability the family was facing. However, it was during her senior year that her mother's welfare benefits were reduced and her younger brother, Suny was sent to a juvenile camp for excessive truancy. Kolab landed a job through her cousin at a fast food restaurant where she worked as much as she could. She graduated with a 3.0 grade point average much to her disappointment. Kolab reflects on how she tried to fulfill school and family responsibilities in high school:

I did pretty good. I chose the right friends and stuff. Friends that don't ditch, you know. And I have most of my class with my friends, so if I need help and stuff, I just call her up and you know we do our stuff together. Well, I have up and down in fact. Sometimes, I can't really understand stuff or get a fact straight, you know. School was kind of hard. When I get home, I help my sisters and brother, you know, with their homework, and then I do mine. [And] I have to go pick up my brother because he is in elementary [school]. After school I do that and then I go work.

As a result of her family's dire financial situation, Kolab foregoes her acceptance to a four-year university. Instead she secures a part-time job tutoring high school students while she attends junior college. With the $\$ 800$ per month Kolab earns, the Meng family manages to fill the gap caused by the loss of welfare benefits. Yee reinforces the significance of Kolab's financial contribution to the family:

My daughter, Kolab, helps out with money for her brothers and sisters' clothes and school supplies. Sometimes, I make about $\$ 300$ a month from sewing to support our family. Frankly, we rarely have any money left at the end of the month.

Although the money Kolab earns fulfills the needs of her parents and siblings, she feels uncertain about her future:

First of all, I really need to know what I want to be because I'm undecided. Before I wanted to be a teacher. Now I want to change that plan. It's going take too long, right? Just to be a teacher.

Kolab's uncertainty stems from not knowing if she can financially afford to focus on her aspiration to become a teacher when the monetary return may be too far in the future to help her family immediately. Although she decides to go to a two-year college, this was not what she wanted nor did it reflect her capabilities. Her job as a tutor, which would have provided the experience needed to become a teacher, was temporarily funded through a grant that eventually ended. Kolab found a job as a waitress, which took her further from her dream to become a teacher. Six years later Kolab is still uncertain about what she wants to do: 
I want to be a good role model for my brothers and sisters, so they graduate and they want to go to college and get a better job. If you just graduate from [high school], you won't do well. Like I did and just get a job. Go to college and study something you like.

Kolab finds herself stuck in junior college with no real direction. She earns enough money as a waitress to help her family, but she still does not know what she wants to do. She is thinking about being a chef, but her family's constant financial crises have caused her to drop classes.

\section{Discussion}

The Meng family faced difficulties coping with the changes in the welfare system in several ways. First, the physical and emotional hardship faced by the parents, Yee and Virath, was typical of other Cambodian families in the study. The loss of SSI and Medi-Cal caused them to have to work harder despite their illnesses and to, in some cases, go without health benefits. Another type of hardship affecting Cambodian families on welfare is the consequences of children getting into trouble. Rules existed before welfare reform that required documentation of children's school attendance. In the new system, the rules became more stringent and consequential. It provides another reason to cut welfare payments, which in turn causes more financial problems. Finally, the vicious cycle of losing benefits makes it necessary to tap into the labor of youth even though parents would prefer their children to attend college. For Kolab, her aspirations are minimized in the face of the family's troubles. She then makes choices to benefit her parents and siblings while deferring or denying her own dreams, a pattern that emerges in the next family case study, but under different circumstances.

\section{The Sok Family}

In 1990, Khun's husband was hit by a stray bullet while he smoked a cigarette behind the family's apartment building. At 38 years old, Khun became a single mother with five young children. Before this terrible personal tragedy, Khun suffered from severe headaches, nightmares, and fainting spells caused by the constant beatings during the Khmer Rouge reign. Because of her poor health, she received SSI.

Over the years, Khun's children convinced her to never remarry, so they would not have a stepfather to worry about. Kosal, the eldest son and Narun, the eldest daughter, promised to take care of her when she gets older. As the younger children grew up they have also helped to support their mother. In return, Khun, despite failing health, worked hard to provide for her children as they were growing up. She supplemented her SSI check by doing various cash jobs working in Cambodian businesses, sewing in the home, and at one point, running a numbers game based on the California lottery. When her children converted to Christianity, she did not object even though she remained a Buddhist. Over the years, the children received homework help from church families and received scholarships for weekend trips and music lessons; activities Khun would not have been able to provide for her children otherwise.

When the Welfare Act was passed, Khun, like Yee lost her SSI benefits. Thrust into the CalWORKS program and in need of a job to continue to receive public assistance, Khun sought help from a program serving the disabled and refugees. In the summer of 1998, she was hired to work on an assembly line that was going to be used as a welfare-to-work training site (herein 
referred to as Project Hope). The first year at Project Hope, Khun was paid by the piece. She describes the work and pressure she felt to complete a task:

Sometimes at my work, I have to fill each box with 100 nails. You know how long it takes to count 100 nails! Each filled box I'm paid one cent, so I made between $\$ 4$ to $\$ 5$ a day. Sometimes I package plates in boxes and sometimes I wrap things. There are many kinds of things that I put in packages. It's hard for me to talk about my work.

Although Khun's work at Project Hope counted toward her work requirements, the program exploited vulnerable immigrant women's labor for profit under the guise of being a training program. Khun did not complain about the work conditions or the low compensation, since the alternative was entering the regular labor market, which she feared even more.

When Project Hope became an official welfare-to-work training site, Khun received a regular salary of $\$ 5.75$ per hour. However, health problems started to affect her ability to function and she needed to take time off:

My arm hurts again and I lost six pounds at work. My doctor is worried about my condition. He is afraid I may collapse at work. I don't know. I keep having dizzy spells and I keep losing weight. And I lost my appetite.

Khun acknowledges that the only reason she is able to keep her job at Project Hope is because of the flexible hours and work conditions:

If I had to work at other places, I don't think I would be able to work many hours. At Project Hope, people do understand my medical condition. If I'm not feeling well, they put me to work on an easy job like labeling on packages or boxes where I can sit down to work.

Since Project Hope was designed with disabled and non-English speaking clients in mind, Khun is able to fulfill work requirements and continue to support her children. Unfortunately, after working for over three years at Project Hope, Khun-as well as many other women in the program were - laid off. The program became a temporary training facility and long term clients like Khun were told "you have all the skills you need to find a job." On the contrary, Khun needed Project Hope to survive, because her health conditions prevent her from being able to work a regular job.

Much of the financial and emotional pressure in the family after Khun loses her job falls on Kosal and Narun, the two eldest children in the family. The Sok family's difficulties come at a critical time for Kosal and Narun. As a senior and junior in high school respectively they are making critical decisions about their educational and work goals. It is also at the same time that Khun gets a portion of the welfare grant discontinued for not meeting work requirements. Kosal receives a call from a welfare caseworker:

They called me in and told me that they will continue to give us cash until I graduate [from high school] in June. I was thinking that they were supposed to help you until you're 25. But no, they said they're cutting me off at 18. I don't understand. 
The welfare caseworker fails to tell Kosal that he and his siblings can continue to receive public assistance if they attend college full time. Instead the caseworker makes it clear that he can no longer count on public assistance implying he must find a job to help support the family. When Kosal and Narun do get jobs to help, they are further penalized for bringing in additional income for the family. Narun describes the progressive loss of welfare resources her family experienced and the limitation it places on the ability to plan for the future:

First of all, it [welfare] helped us. But second of all, they [the caseworkers] kept cutting us off. And then the doctor can't find anything wrong with mom, so you're lying. So, even though my mom was sick, it didn't matter. So they cut off her SSI. And then they [learned] my brother is working and I was working. We brought income to the family, so they cut us off more. And I'm like, "Okay. What are you guys doing?" It's just weird. And the policy, they help, but then again, not really.

Being subject to digressive welfare rules frustrates these youth and makes it difficult to fulfill their goals and help support their families.

Kosal as the oldest in the family feels tremendous pressure to support the family especially after the conversation with the caseworker. Before he finishes high school Kosal enlists in the army instead of attending college as planned, a decision his mother and sisters objected to. Khun explain her son's decision this way: "I'm worried about him going into the military. Maybe he doesn't feel confident in knowing what career he can do. Maybe he's feeling he wants to make sure his mother is going to be okay." Once he receives his monthly stipend from the army, Kosal sends \$200-300 every month to his mother and sisters.

When Kosal leaves, Narun must assume more responsibility for the day-to-day functioning of the family. Since Khun regularly passes out, Narun balances her studies and her job at a fast food restaurant with family chores, taking care of her three younger sisters and getting Khun to doctor appointments. She is also tacitly expected to help pay for her younger sister's extracurricular activities. Lina, the youngest and the academic superstar in the family, is a cheerleader and musician. Narun expresses her discontent with supporting Lina while she works and tries to finish high school:

How she going to be in all these, what you call it, clubs? She thinks that we're going to just support her. I'll support you all right, but you can't be getting everything you want. I told her you gonna get yourself a job at sixteen or seventeen. You're going to learn to deal with people and take those rude customers. I told her, "How you expect to buy your letterman jacket, your ring?" We have to buy everything. I didn't even get my senior ring. I don't have any money.

Narun expresses a common feeling among youth in this study. They feel an obligation to be good role models for their younger siblings by choosing the right path. However, the pressure to fulfill these family obligations has become more difficult with changes in the financial circumstances of their parents. It is more difficult to balance personal aspirations with the need to work to help support their parents and siblings. For Narun, the pressure became too great and she dropped out of high school her last semester so she could work more hours at a fast food restaurant. In reality, she is despondent about her future. She confides she dreams of being a photographer, a career 
she believes her family would consider too impractical and costly to pursue. Unfortunately, she is not able to pursue any career without a high school diploma.

By 2003, the Sok family's circumstances change somewhat for the better. Khun is able to qualify for The Cash Assistance Program for Immigrants (CAPI), a State of California financial assistance program for aged or disabled legal immigrant who was previously denied SSI under federal law. The Sok family also qualified for a Section 8 Housing voucher. Even with these positive financial shifts in the family, the work and educational trajectories of Khun's children had been altered. Lina, the "A" student, with the greatest potential to attend a four year university is floundering at a junior college. She decided in high school to pursue culinary arts, a program she did not finish:

The thing is that I needed a stress reliever when I was in high school, because I was not sure about what I was going to do and I was just working. I found out about ROP [Regional Occupational Program] program at school. The ROP program you have to pay for it if you're not in high school. So I was like looking around at all the stuff and I saw culinary arts and I like to cook because whenever there was a big party my mom's friends always called me over. And I used to help make the food. So I took the culinary arts program in the ROP program for almost a full year and then I got sick so I couldn't finish it.

Lina continues to pursue her dream of becoming a chef at the junior college, but she is often distracted by family financial problems and with taking care of her mother:

Its hard because my mom doesn't speak English and she can't work. She's always had these [health] problems where she can't work because her body's not functioning right. I think it's kind of strained the family, because we have to work you know work just to keep afloat and it's kind of clashes with school.

Lina acknowledges the effect her mother's health has had on them and the ability to attain higher education.

\section{Discussion}

The five Sok children have stayed out of trouble and tried to fulfill their family obligations. They had the potential and the grades for higher education, but could not afford pursuing personal goals in the face of dire financial circumstances and their mother's health problems. Narun eventually received her GED (General Education Development) or high school equivalency. However, like all the youth in this study, none of the Sok children have graduated from a 4-year university or entered a career that has helped the family move out of poverty with the exception of Kosal who is in the military. This option would not be available to all the other boys in the study, since they had difficulties in school with truancy and with academics overall.

Although growing up in a single parent family, the Sok children are not disadvantaged by the structure of their family. Instead, they are disadvantaged by the welfare program changes that penalize refugees who suffer health conditions and who have few skills to allow them to find viable jobs and rules about income levels of youth in the family. Their limited choices cause tensions within the family even though a strong sense of family obligation can lead to greater 
aspirations (Gibson \& Weisner, 2002). In the current welfare system, Cambodian youth's "carrying capacity" exceeds their ability to balance family, work, and school obligations (Burnham, 2001). A strong sense of parental and sibling obligation may be misinterpreted as a cultural deficit (Gennetian, Duncan, Knox, et al., 2004, 2000), but this is because the actions of youth are viewed outside the logic and meaning of family survival strategies that have been threatened by policies that disadvantage poor youth. The loss of public assistance to their families contributes to their decision to take low wage jobs rather than toward educational opportunities, which would increase their social mobility but would not address the immediate needs of their family members.

\section{Looking Forward in the Post-Welfare Era}

Since this study ended, the U.S. has experienced one of the worst economic downturns since the Great Depression. In response, Congress passed The American Recovery and Reinvestment Act of 2009 to create a new TANF emergency fund to assist states in expanding services during the recession, offering a trifling of resources for a growing number of new and recurrent needy families. The TANF block grant program was scheduled for Congressional reauthorization in 2010. Instead, Congress has extended the TANF block grant each year since then with no plans to consider the future of needy families in this country. These tentative Congressional actions leave states and counties in a difficult position to meet the needs of poor and vulnerable families — such as Cambodians — in an uncertain economy.

The purpose of this study was to explore the impact of Welfare Reform in first generation Cambodian families and how the youth coming of age were impacted by this policy change. The research findings and family case histories presented in this article illustrate the shared struggle of Cambodian family members in poverty and the significant challenges second generation Cambodian Americans face in the current economy and welfare policy context. Growing up within the constraints of welfare policies that systematically undercut their family survival strategies made it difficult for all the youth in this study to achieve higher education goals.

The families that fared slightly better economically during and after Welfare Reform were the ones that received various forms of public assistance and had older children that worked. However, much of the gains from accessing new streams of public assistance were counterbalanced by other cuts in benefits when older youth aged-out of the system or if one of the children got into trouble in school. The constant cycle of economic uncertainty made it difficult for the family to save money or plan for the future. This created the unintended consequence of relying more and more on their children, mainly the girls, for support even though parents wanted them to finish school and get good jobs.

Research findings emanating from this study provide critical background on how constant economic insecurity operate within the context of family daily routines and obligations (e.g., parental and sibling) in Cambodian families. This study contextualizes lingering questions about persistent poverty in the Cambodian community; the need for greater educational attainment among the next generation; and the development of work opportunities that address the unique circumstances of genocide survivors.

Looking forward, I would like to highlight how the findings from this study can inform future research and programs in Cambodian American and other Southeast Asian communities. 
1. $\quad$ Studying issues of poverty and welfare usage requires a change in perception. The U.S. economy is unstable and enters periods of decline that disproportionately impact those already on the economic margins with less education and few job skills (Brenner, 1998; Piven, 2001). During the course of this study, Cambodian youth expressed shame about welfare and their families' economic status, reflecting the broader society's stereotypes. This may prevent youth from seeking assistance or guidance on how to enter college or manage work and school. Social service providers need to know the realities of living in poverty and the constant uncertainty faced by parents and youth. In order to advocate for and to serve the most vulnerable families requires an understanding of the role of welfare as a survival strategy in families.

2. Seek to understand family survival strategies within the context of current economic and policy context. As this study illustrates, Cambodian families rely upon the financial and emotional contributions of both the older and younger generation to enable the social and economic well-being of the family. Family survival strategies are creative mechanisms to achieve culturally valued goals, including the attainment of higher education. By understanding family survival strategies, rather than narrowly focusing on the individual welfare recipient, the meaning and purpose of welfare can be further studied in Cambodian families and in other Southeast Asian communities. Programs need to contextualize and address the shared struggle across the generations especially in the poorest families. Youth programs should recognize that despite intergenerational conflicts, parents and children often work together to ensure economic security. Parental and sibling obligation can lead to a sense of responsibility and inspire achievement; however these relationships have been portrayed as a potential detriment to individual achievement (Gennetian, Duncan, Knox, et al., 2004).

3. Understand gender and generational differences in family roles and expectations. Each Southeast Asian culture has undergone tremendous change since coming to the U.S. and this has impacted gender and generational roles and responsibilities within the family. This study shows the long term impact of first generation Cambodians' health and mental health status due to war trauma. Their past trauma must be viewed within the context of current issues surrounding economic and social struggles in poverty. Studies suggest that Cambodian girls and boys experience different barriers to achieving higher education and work opportunities (Chhuon, Hudley, Brenner, \& Macias, 2010). Girls and boys have different experiences in their neighborhoods and in the educational system that impact their possible futures. This study also suggests that gender roles are linked to sibling relationships and obligations that requires further study to fully appreciate how it may impact life trajectories (cf. Smith-Hefner, 1999).

4. Longitudinal qualitative research and future research. The findings discussed in this article provide an in-depth view of the everyday struggles of Cambodian families on welfare. The longitudinal qualitative research strategy provides critical information about the intersections between policy change processes and family-level impacts seldom revealed in statistical analysis. The limitations of this approach are the small number of families that can be studied at any given time and thus the inability to generalize the findings. However, understanding the role of public assistance as an economic 
buffer for families can lead to better interventions with youth and families at the program and educational level. Additional research is needed to identify if the lower attainment of higher education in Cambodian communities (as well as in Laotian and Hmong communities) can be traced to the poorest members of these communities (cf. Sakamoto \& Woo, 2007). If this is the case, as findings from this study suggest, then better advocacy for immigrants and refugees can emphasize how public resources enable children's success. However, these findings need to be contextualized within the varied experiences and challenges faced by different Southeast Asian groups.

\section{References}

Alba, R., \& Nee, V. (2003). Remaking the American mainstream: Assimilation and contemporary immigration. Cambridge, UK: Harvard University Press.

Becker, E. (1998). When the war was over: Cambodians and the Khmer Rouge revolution. New York, NY: Public Affairs.

Becker, G., Beyene, Y., \& Ken, P. (2000). Health, welfare reform, and narratives of uncertainty among Cambodian refugees. Culture, Medicine and Psychiatry, 24, 139-163.

Bernard, H. R. (2000). Social research methods: Qualitative and quantitative approaches. Thousand Oaks, CA: Sage.

Blair, R. G. (2000). Risk factors associated with PTSD and major depression among Cambodian refugees in Utah. Health and Social Work, 25(1), 23-30.

Brenner, R. (1998). The economics of global turbulence. New Left Review, 229, 1-265.

Burnham, L. (2001). Welfare reform, family hardship, and women of color. The ANNALS of the American Academy of Political and Social Science, 577, 38-48.

Chan, S. (2004). Survivors: Cambodian refugees in the United States. Chicago, IL: University of Illinois Press.

Chandler, D. P. (1991). The tragedy of Cambodian history: Politics, war, and revolution since 1945. New Haven, CT: Yale University Press.

Cheng, L. H., \& Yang, P. Q. (1996). Asians: The "model minority" deconstructed. In R. Waldinger \& M. Bozorgmehr (Eds.), Ethnic Los Angeles (pp. 305-344). New York, NY: Russell Sage Foundation.

Chhuon, V., Hudley, C., Brenner, M. E., \& Macias, R. (2010). The multiple worlds of successful Cambodian American students. Urban Education, 45(1), 30-57.

Edin, K., \& Lein, L. (1997). Making ends meet: How single mothers survive welfare and low wage work. New York, NY: The Russell Sage Foundation.

Fetterman, D. M. (1998). Ethnography: Step by step (2nd ed.). Thousand Oaks, CA: Sage.

Fix, M. E., \& Zimmerman, W. (1997). Immigrant families and public policy: A deepening divide. In A. Booth, A. C. Crouter, \& N. Landale (Eds.), Immigration and the family: Research and policy on U.S. immigrants (pp. 237-262). Mahwah, NJ: Lawrence Erlbaum Associates Publishers.

Fix, M. E., Capps, R., \& Kaushal, N. (2009). Immigrants and welfare: Overview. In M. E. Fix (Ed.), Immigrants and Welfare: The impact of welfare reform on America's newcomers (pp. 1-36). New York, NY: Russell Sage Foundation.

Fujiwara, L. H. (1999). Asian immigrant communities and the racial politics of welfare reform. In G. Mink (Ed.), Whose welfare? (pp. 100-131). New York, NY: Cornell University Press. 
Fujiwara, L. H. (2005). Immigrant rights are human rights: The reframing of immigrant entitlement and welfare. Social Problems, 52(1), 79-101.

Fuligni, A., \& Yoshikawa, H. (2004). Investments in children among immigrant families. In A. Kalil \& T. DeLeire (Eds.), Family investments in children's potential: Resources and parenting behaviors that promote success (pp. 135-158). Mahwah, NJ: Lawrence Erlbaum Associates Publishers.

Gans, H. (1992). Second generation decline: Scenarios for the economic and ethnic futures of post-1965 American immigrants. Ethnic and Racial Studies, 15, 173-192.

Gennetian, L. A., Duncan, G. J., Knox, V. W., Vargas, W.G., Clark-Kauffman, E., \& London, A. S. (2000). How welfare and work policies for parents affect adolescents: $A$ synthesis of research. New York, NY: Manpower Demonstration Research Corporation.

Gennetian, L. A., Duncan, G. J., Knox, V. W., Vargas, W. G., Clark-Kauffman, E., \& London, A. S. (2004). How welfare policies affect adolescents' school outcomes: A synthesis of evidence from experimental studies. Journal of Research on Adolescence, 14(4), 399-423.

Gibson, C. M., \& Weisner, T. S. (2002). "Rational" and ecocultural circumstances of program take-up among low-income working parents. Human Organization, 61(2), 154-166.

Greenberg, M. (2001). Welfare reform and devolution. Brookings Review, 19, 20-24.

Greenberg, M., Levin-Epstein, J., Hutson, R., Ooms, T., Schumacher, R., Turesky, V., \& Engstrom, D. (2000). Welfare reauthorization: An early guide to the issues. Washington, DC: Center for Law and Social Policy.

Hein, J. (2006). Ethnic origins: The adaptation of Cambodian and Hmong refugees in four American cities. New York, NY: Russell Sage Foundation.

Hoeffel, E. M., Rastogi, S., Kim, M. O., \& Shahid, H. (2012). The Asian Population: 2010. Washington, DC: U.S. Census Bureau.

Horton, J., \& Shaw, L. (2002). Opportunity, control and resistance: Living welfare reform in Los Angeles County. In F. F. Piven, J. Acker, M. Hallock, \& S. Morgen (Eds.), In Work, welfare and politics: Confronting poverty in the wake of welfare reform (pp. 197212). Eugene, OR: University of Oregon Press.

Kibria, N. (1993). Family tightrope: The changing lives of Vietnamese Americans. Princeton, NJ: Princeton University Press.

Kiernan, B. (1996). The Pol Pot regime: Race, power, and genocide in Cambodia under the Khmer Rouge 1975-1979. New Haven, CT: Yale University Press.

Kinzie, J. D., \& Frederickson, R. H. (1984). Post-traumatic stress disorder among survivors of Cambodian concentration camps. American Journal of Psychiatry, 141(5), 645-650.

Lofland, J., \& Lofland, L. (1984). Analyzing social settings: A guide to qualitative observation (2nd ed.). Belmont, CA: Wadsworth.

Macartney, S., Bishaw, A., \& Fontenor, K. (2013). Poverty rates for selected detailed race and Hispanic groups by state and place: 2007-2011. Washington, DC: U.S. Census Bureau American Community Survey Briefs.

Marchevsky, A., \& Theoharis, J. (2006). Not working. Latina immigrants, low wage jobs, and the failure of welfare reform. New York, NY: New York University Press.

Marshall, G. N., Schell, T. L., Elliott, M. N., Berthold, S. M., \& Chun, C. A. (2005). Mental health of Cambodian refugees 2 decades after resettlement in the United States. Journal of the American Medical Association, 294, 571-579.

Mautino, K. S. (2000). Welfare reform: An update. Journal of Immigrant Health, 2(1),1-5. 
Mollica, R. F., Wyshak, G., Lavelle, J. (1990). Assessing symptom change in Southeast Asian refugee survivors of mass violence and torture. American Journal of Psychiatry, 147(1), 83-88.

Needham, S., \& Quintiliani, K. (2007). Cambodians in Long Beach, California: The making of a community. Journal of Immigrant and Refugee Studies, 5(1), 29-53.

Newman, K. S. (1999). No shame in my game: The working poor in the inner city. New York, NY: Alfred A. Knopf and Russell Sage Foundation.

Newman, K. S. (2001). Hard times on 125th street: Harlem's poor confront welfare reform. American Anthropologist, 103(3), 762-778.

$\mathrm{Ng}$, D. (2004). Welfare reform in Santa Clara County: The experiences of Mexican and Vietnamese immigrant women. In P. Kretsedemas \& A. Aparicio (Eds.), Immigrants, Welfare Reform, and the poverty of policy (pp. 159-186). Westport, CT: Praeger.

$\mathrm{Ng}$, D. (2002). From war on poverty to war on welfare: The impact of welfare reform on the lives of immigrant women. In F. F. Piven, J. Acker, M. Hallock, \& S. Morgen (Eds.). Work, welfare and politics: Confronting poverty in the wake of welfare reform (pp. 277288). Eugene, OR: University of Oregon Press.

Niedzwiecki, M., \& Duong, T. C. (2004). Southeast Asian American statistical profile. Washington, DC: Southeast Asia Resource Action Center (SEARAC).

O’Connor, A. (2001). Poverty knowledge: Social science, social policy, and the poor in twentieth-century U.S. history. Princeton, NJ: Princeton University Press.

Ong, A. (2003). Buddha is hiding. London, UK: University of California, Ltd.

Ong, P., \& Blumenberg, E. (1994). Welfare and work among Southeast Asians. In P. Ong (Ed.), The state of Asian pacific America: Economic diversity, issues, and policies: a public policy report (pp. 113-138). Los Angeles, CA: LEAP Asian Pacific American Public Policy Institute and UCLA Asian American Studies Department.

Palumbo-Liu, D. (1999). Asian/American: Historical crossings of a racial frontier. Stanford, CA: Stanford University Press.

Portes, A., \& Borocz, J. (1989). Contemporary immigration: Theoretical perspectives on its determinants and modes of incorporation. International Migration Review, 23(3), 606630.

Portes, A., \& Rumbaut, R. (1996). Immigrant America: A portrait (2nd ed.). Berkeley, CA: University of California Press.

Piven, F. F. (2001). Welfare reform and the economic and cultural reconstruction of low wage labor markets. In J. Goode \& J. Maskovsky (Eds.). The new poverty studies: The ethnography of power, politics and impoverished people in the United States (pp. 135151). New York, NY: New York University Press.

Quint, J., Edin, K., Buck, M. L., Fink, B., Padilla, Y. C., Simmons-Hewitt, O., \& Valmont, M. E. (1999). Big cities and welfare reform: Early implementation and ethnographic findings from the project on devolution and urban change. New York, NY: Manpower Demonstration Research Corporation.

Quintiliani, K. (2009). Cambodian refugee families in the shadows of welfare reform. Journal of Immigrant and Refugee Studies, 7, 129-158.

Quintiliani, K. (2003). From streets of gold to streets of struggle: Khmer families and the social and economic consequences of welfare reform. (Unpublished doctoral dissertation). University of California, Los Angeles. 
Rumbaut, R. G. (2006). Vietnamese, Laotian and Cambodian Americans. In P. G. Min (Ed.), Asian Americans: Contemporary trends and issues (2nd ed., pp. 262-289). Thousand Oaks, CA: Sage Publications.

Rumbaut, R. G. (1996). A legacy of war: Refugees from Vietnam, Laos, and Cambodia. In S. Pedraza \& R. Rumbaut (Eds.), Origins and destinies: Immigration, race, and ethnicity in America (pp. 315-333). London, UK: Wadsworth.

Sakamoto, A., \& Woo, H. (2007). The socioeconomic attainments of second-generation Cambodian, Hmong, Laotian, and Vietnamese Americans. Sociological Inquiry, 77(1), 44-75.

Schneider, J. (2000). Pathways to opportunity: The role of race, social networks, institutions and neighborhood in career and educational paths for people on welfare. Human Organization, 59(1), 72-85

Sharff, J. W. (1998). King Kong on $4^{\text {th }}$ street: Families and the violence of poverty on the lower east side. Boulder, CO: Westview Press.

Shields, J. (2004). No safe haven: Work, welfare, and the growth of immigrant exclusion. In P. Kretsedemas \& A. Aparicio (Eds.), Immigrants, welfare reform, and the poverty of policy (pp. 35-62).Westport, CT: Praeger.

Singer, A. (2004). Welfare reform and immigrants: A policy review. In P. Kretsedemas \& A. Aparicio (Eds.), Immigrants, welfare reform, and the poverty of policy (pp. 21-34). Westport, CT: Praeger.

Smith-Hefner, N. (1999). Khmer American: Identity and moral education in a diasporic community. Berkeley, CA: University of California Press.

Spradley, J. P. (1980). Participant observation. London, UK: Wadsworth/Thomson Learning.

Southeast Asia Resource Action Center. (2011). Statistics on Southeast Asians adapted from the American Community Survey. Washington DC: SEARAC.

Stake, R. E. (2003). Case studies. In N. K. Denzin \& Y. S. Lincoln (Eds.), Strategies of qualitative inquiry (2nd ed., pp. 89-109). Thousand Oaks, CA: Sage Publications.

Takei, I., \& Sakamoto, A. (2011). Poverty among Asian Americans in the $21^{\text {st }}$ century. Sociological Perspectives, 54(2), 251-276.

Tang, E. (2000). Collateral damage: Southeast Asian poverty in the United States. Social Text, $18(1), 55-79$.

Toji, D., \& Johnson, J. (1992). Asian and Pacific Islander American poverty: The working poor and the jobless poor. Amerasia Journal, 18, 83-91.

Truong, M. H. (2007). Welfare reform and liberal governance: Disciplining CambodianAmerican bodies. International Journal of Social Welfare, 16, 258-268.

U.S. Census Bureau. (2011). 2011 American Survey 1-year estimates. Retrieved from http://factfinder2.census.gov/faces/nav/jsf/pages/index.xhtml

U.S. Census Bureau. (2010). 2006-2010 American Community Survey Selected Population Tables. Retrieved from http://factfinder2.census.gov/faces/nav/jsf/pages/index.xhtml

Wright, W. E., \& Boun, S. Southeast Asian American education 35 years after initial resettlement: Research report and policy recommendations. Journal of Southeast Asian American Education \& Advancement, 6, 1-77.

Zhou, M. (1999). Coming of age: The current situation of Asian American children. Amerasia Journal, 25, 1-27.

Zhou, M. (1997). Growing up American: The challenge confronting children of immigrants. Annual Review of Sociology, 23,3-95. 
Zhou, M., Lee, J., Vallejo, J.A., Tafoya-Estrada, R., \& Xiong, Y. S. (2008). Success attained, deterred, and denied: Divergent pathways to social mobility in Los Angeles' new second generation. The ANNALS of the American Academy of Political and Social Science, 620, $37-61$.

\title{
Notes
}

${ }^{1}$ In addition to the participants enumerated in Table 1, a total of 109 other family members and friends were observed in the context of daily routines in these families (See Quintiliani, 2003 for further discussion about family obligations and neighborhood conditions).

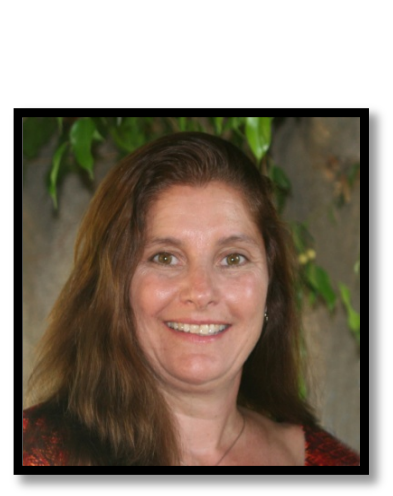

\begin{abstract}
About the Author
Karen Quintiliani is an Associate Professor and the Chair of the Department of Anthropology at California State University, Long Beach. She has conducted ethnographic and applied research in the Long Beach Cambodian community since 1988. She has worked as an applied anthropologist for community based organizations, specializing in developing and implementing programs focused on community health and education for Southeast Asians and their children. Her research, publications, and community engagement projects include: cultural history of the Cambodian immigrant experience; social welfare policy; gender and sexuality; refugee
\end{abstract} and immigrant health; youth cultures; and program development and evaluation. She is the co-founder and director with Dr. Susan Needham of the Cambodian Community History \& Archive Project (www.camchap.org). 


\title{
A peer-reviewed JSAAEA Journal of Southeast Asian American Education \& Advancement \\ Volume 9 (2014) \\ WwW.JSAAEA.org \\ and Vietnamese \\ Americans (NAFEA)
}

\author{
Editor \\ Dr. Wayne E. Wright \\ University of Texas at San Antonio \\ Associate Editors \\ Dr. Chhany Sak-Humphry \\ University of Hawaii at Manoa \\ Dr. Phitsamay Sychitkokhong Uy \\ University of Massachusetts, Lowell

\section{Book Review Editor} \\ Dr. Vichet Chhuon \\ University of Minnesota

\section{Creative Works Editor} \\ Bryan Thao Worra \\ Lao Assistance Center

\section{Special Advisor} \\ Gregory Green \\ Curator, Echols Collection on Southeast Asia, Cornell University Library

\section{Journal Manager} \\ Yeng Yang \\ University of Texas at San Antonio
}

\section{Editorial Assistant}

Matthew Kraft

University of Texas at San Antonio

Comments and questions for the editorial staff may be directed to jsaaea@lists.sis.utsa.edu

\section{Editorial Review Board}

Dr. Steve Arounsack

California State University, Stanislaus

Dr. Phala Chea

Lowell Public Schools

Dr. Loan Dao

University of Massachusetts, Boston

Dr. Changming Duan

University of Missouri, Kansas City
Dr. Carl L. Bankston III

Tulane University

Dr. George Chigas

University of Massachusetts, Lowell

Dr. Hien Duc Do

San Jose State University

Dr. Sophal Ear

U.S. Naval Postgraduate School

Journal of Southeast Asian American Education \& Advancement, Vol. 9 (2014) 


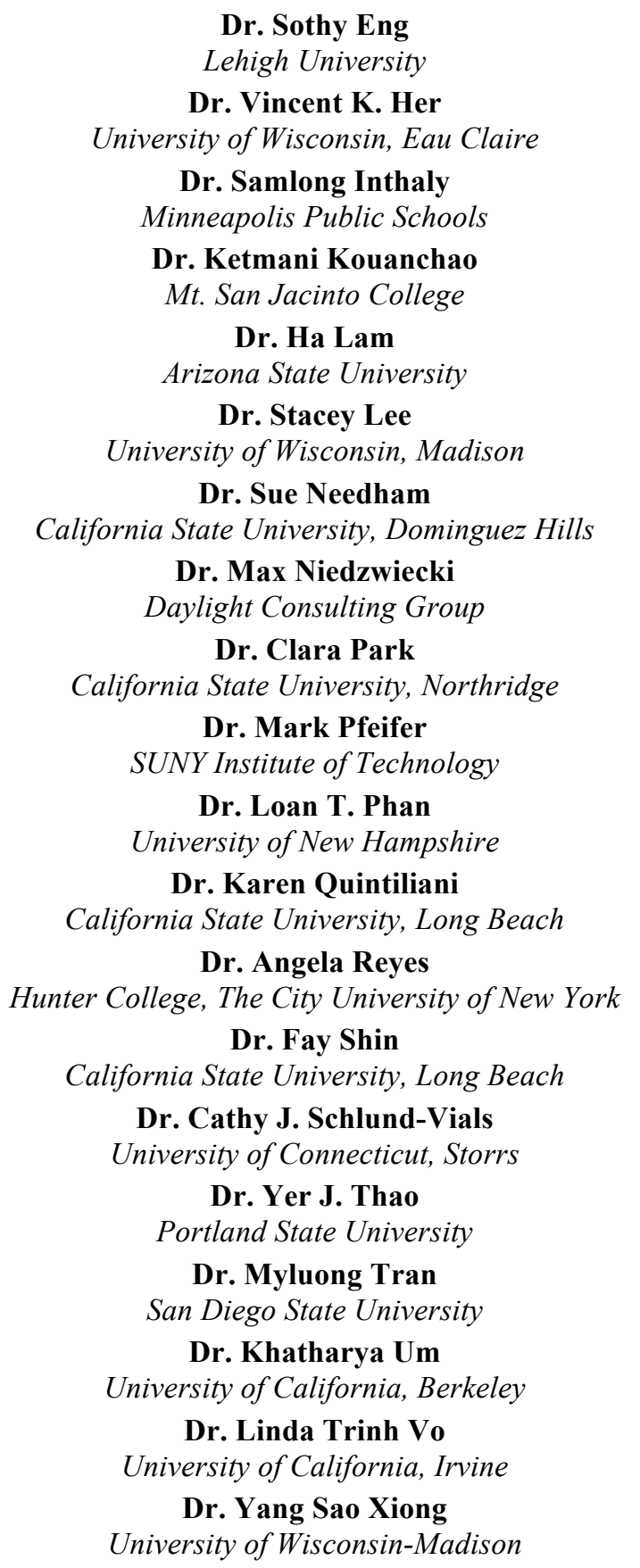

\section{Doctoral Student Editorial Review Board}

Sovicheth Boun

University of Texas at San Antonio

Keo Chea-Young

University of Pennsylvania

Dung Mao

University of Minnesota
Dr. Jeremy Hein

University of Wisconsin, Eau Claire

Dr. Nancy H. Hornberger

University of Pennsylvania

Dr. Peter Nien-Chu Kiang

University of Massachusetts, Boston

Dr. Kevin K. Kumashiro

University of Illinois, Chicago

Dr. Jonathan H. X. Lee

San Francisco State University

Dr. Monirith Ly

Texas State University-San Marcos

Dr. Bic Ngo

University of Minnesota

Dr. Leakhena Nou

California State University, Long Beach

Dr. Isabelle Thuy Pelaud

San Francisco State University

Dr. Giang Pham

University of Massachusetts

Dr. Bounlieng Phommasouvanh

Minnesota Department of Education

Dr. Kalyani Rai

University of Wisconsin, Milwaukee

Dr. Soveacha Ros

Royal University of Phnom Penh

Dr. Nancy J. Smith-Hefner

Boston University

Dr. Christine Su

Ohio University

Dr. Loan Tran

University of California, Riverside

Dr. Tinou Tran

Alief Independent School District

Dr. Silvy Un

Frost Lake Elementary School

Dr. Terrence G. Wiley

Center for Applied Linguistics

Dr. Zha Blong Xiong

University of Minnesota 
Quintiliani: A Qualitative Study of the Long Term Impact of Welfare Reform on

Quintiliani-Long Term Impact of Welfare Reform on Cambodian American Families

Ravy Lao

University of California, Santa Barbara

Thien-Huong Ninh

University of Southern California

Malaphone Phommasa

University of California, Santa Barbara

Alisia Tran

University of Minnesota
Minh Mai

University of Wisconsin-Madison

Hoa Nha Nguyen

Boston College

Vanna Som

Harvard University

Krissyvan Truong

Claremont Graduate University

\section{Lesley Yang}

University of Minnesota 